\title{
Loss of $\mathrm{Hfe}$ Leads to Progression of Tumor Phenotype in Primary Retinal Pigment Epithelial Cells
}

\author{
Jaya P. Gnana-Prakasam, ${ }^{1}$ Rajalakshmi Veeranan-Karmegam, ${ }^{1}$ \\ Veena Coothankandaswamy, ${ }^{1}$ Sushma K. Reddy, ${ }^{1}$ Pamela M. Martin, ${ }^{1}$ \\ Muthusamy Thangaraju, ${ }^{1}$ Sylvia B. Smith, ${ }^{2}$ and Vadivel Ganapathy ${ }^{1}$
}

Purpose. Hemochromatosis is a disorder of iron overload arising mostly from mutations in HFE. HFE is expressed in retinal pigment epithelium (RPE), and $\mathrm{Hfe}^{-{ }_{-}^{-}}$mice develop agerelated iron accumulation and retinal degeneration associated with RPE hyperproliferation. Here, the mechanism underlying the hyperproliferative phenotype in RPE was investigated.

Methods. Cellular senescence was monitored by $\beta$-galactosidase activity. Gene expression was monitored by real-time PCR. Survivin was analyzed by Western blot and immunofluorescence. Migration and invasion were monitored using appropriate kits. Glucose transporters (GLUTs) were monitored by 3$O$-methyl-D-glucose uptake. Histone deacetylases (HDACs) were studied by monitoring catalytic activity and acetylation status of histones $\mathrm{H} 3 / \mathrm{H} 4$.

REsults. $\mathrm{Hfe}^{-/-}$RPE cells exhibited slower senescence rate and higher survivin expression than wild type cells. $\mathrm{Hfe}^{-/}$cells migrated faster and showed greater glucose uptake and increased expression of GLUTs. The expression of HDACs and DNA methyltransferase (DNMTs) also was increased. Similarly, RPE cells from hemojuvelin (Hjv)-knockout mice, another model of hemochromatosis, also had increased expression of GLUTs, HDACs, and DNMTs. The expression of Slc $5 \mathrm{a} 8$ was decreased in $\mathrm{Hfe}^{-{ }^{-}-} \mathrm{RPE}$ cells, but treatment with a DNA methylation inhibitor restored the transporter expression, indicating involvement of DNA methylation in the silencing of Slc5a8 in $\mathrm{Hfe}^{-/-}$cells.

Conclusions. RPE cells from iron-overloaded mice exhibit several features of tumor cells: decreased senescence, enhanced migration, increased glucose uptake, and elevated levels of HDACs and DNMTs. These features are seen in $\mathrm{Hfe}^{-/-}$ RPE cells as well as in $\mathrm{Hj}^{-/-}$RPE cells, providing a molecular basis for the hyperproliferative phenotype of $\mathrm{Hfe}^{-/-}$and $\mathrm{Hjv}^{-/-}$ RPE cells. (Invest Ophthalmol Vis Sci. 2013;54:63-71) DOI: 10.1167/iovs.12-10312

From the Departments of ${ }^{1}$ Biochemistry and Molecular Biology and ${ }^{2}$ Cellular Biology and Anatomy, Georgia Health Sciences University, Augusta, Georgia.

Supported by a grant from the National Eye Institute (EY019672)

Submitted for publication June 2, 2012; revised October 3 and November 9, 2012; accepted November 9, 2012.

Disclosure: J.P. Gnana-Prakasam, None; R. Veeranan-Karmegam, None; V. Coothankandaswamy, None; S.K. Reddy, None; P.M. Martin, None; M. Thangaraju, None; S.B. Smith, None; V. Ganapathy, None

Corresponding author: Jaya P. Gnana-Prakasam, Department of Biochemistry and Molecular Biology, Georgia Health Sciences University, Augusta, GA 30912; jgnanaprakasam@georgiahealth.edu.
$\mathrm{H}$ ereditary hemochromatosis is an autosomal recessive disorder of iron overload. ${ }^{1-5}$ Excess iron is toxic because it can undergo Fenton reaction, catalyzing the conversion of $\mathrm{H}_{2} \mathrm{O}_{2}$ to hydroxyl radical. Hydroxyl radicals in turn cause lipid peroxidation, DNA strand breaks, and degradation of cellular components resulting in tissue damage. ${ }^{6}$ Hemochromatosis patients have morbid iron accumulation in various organs, including the liver, pancreas, kidney, heart, and brain resulting in diverse symptoms such as hepatocarcinoma/cirrhosis, diabetes, nephropathy, cardiomyopathy, and pituitary dysfunction. ${ }^{1-3}$ Most ( $\left.>85 \%\right)$ cases of hemochromatosis are associated with mutations in HFE [Histocompatability leukocyte antigen class I-like protein involved in iron (FE) homeostasis]. ${ }^{7}$ The clinical symptoms of the disease caused by mutations in HFE begin to appear only at relatively older ages ( $>50$ years). The remaining approximately $15 \%$ of mutations occur in hepcidin, hemojuvelin (HJV; also known as HFE2), ferroportin, and transferrin receptor 2 (TfR2), all of which are also important determinants of iron homeostasis. ${ }^{8}$ Mutations in $\mathrm{HJV}$ and hepcidin lead to iron overload at a much younger age, resulting in juvenile hemochromatosis. HFE interacts with $\beta_{2}$-microglobulin, and this interaction is obligatory for the presentation of HFE to the cell surface. In the plasma membrane, HFE interacts with transferrin receptors, TfR1 and TfR2, and inhibits cellular iron uptake. Irrespective of the gene that is mutated in hemochromatosis, there is an increase in intestinal absorption of iron, leading to systemic iron overload. The prevalence of hemochromatosis is quite high, with homozygosity for $H F E$ mutations in the range of approximately 1 in $300 .^{7}$

In the retina, there are many iron-containing proteins that are involved in the phototransduction cascade 9,10 ; hence, it is essential to maintain iron homeostasis for effective functioning of the retina. Apart from reactive oxygen species mediated by photo-oxidation, hemochromatosis patients may have additional oxidative stress due to iron overload in the retina. In the last decade, several studies have shown the expression and function of iron-regulatory proteins in the retina. ${ }^{11-14}$ Disruption or loss of iron-regulatory proteins results in AMD-like phenotype in mouse retinas. ${ }^{15,16}$ Recently, we reported agedependent retinal degeneration in $\mathrm{Hfe}$ and $\mathrm{Hjv}$ knockout mice. ${ }^{17,18}$ Interestingly, we found evidence of hypertrophy and hyperproliferation in retinal pigment epithelial cells (RPE) in both of these mouse models of hemochromatosis. Here we report that $H \mathrm{fe}^{-/-}$RPE cells exhibit several features of tumor cells. These alterations were also found in $\mathrm{Hjv}^{-/-}$RPE cells, indicating that iron overload is the common underlying cause for these phenotypic changes.

Cancer cells are dependent on large amounts of micronutrients like iron for their rapid growth and cell division. There is evidence that high body iron stores increase risk of cancer in humans. ${ }^{19}$ Cancer cells have an uncontrolled capacity for 
proliferation, migration and invasion. Increase in glucose uptake and utilization protects cancer cells from starvation. Tumor progression is not only restricted to the above genetic modifications, it also involves epigenetic changes. Histone acetylation mediated by histone acetyltransferases (HATs) induces gene transcription, whereas histone hypoacetylation mediated by histone deacetylases (HDACs) is associated with gene silencing. Altered expression of HDACs has been linked to tumor development since they affect transcription of genes that regulate critical cellular functions such as cell proliferation, cell-cycle regulation, and apoptosis. ${ }^{20}$ Although hemochromatosis patients have been well documented to have an increased risk in developing tumors, the molecular mechanism by which iron overload leads to increased predisposition to cancer is unknown. In the present study, we found that $\mathrm{Hfe}^{-/-}$ RPE cells have a characteristic tumor phenotype such as increased glucose uptake, enhanced migration, upregulation of survivin, and also epigenetic changes that are found in tumor cells. Most of these findings hold true in $\mathrm{Hjv}^{-/-}$RPE cells as well.

\section{MeTHODS}

\section{Animals}

Breeding pairs of $\mathrm{Hfe}^{+/-}$mice (C56Bl/6 genetic background) were obtained from the Jackson Laboratory (Bar Harbor, ME). Breeding pairs of $\mathrm{Hjv}^{+/-}$mice (Sv129 genetic background) were provided by Nancy Andrews (Duke University School of Medicine, Durham, NC). Genotyping was done to identify wild type, heterozygous, and homozygous mice in the litters. Age-matched and strain-matched wild type and $\mathrm{Hfe}^{-/-}$or $\mathrm{Hjv}^{-/}$mice were selected from the same litters for comparison studies. All procedures involving mice were approved by the Institutional Committee on Animal Use for Research and Education and performed in accordance with the ARVO Statement for the Use of Animals in Ophthalmic and Vision Research.

\section{Establishment of Primary RPE Cell Cultures from Mouse Eyes}

Primary cultures of RPE were prepared as described previously. ${ }^{17,18}$ Young mouse pups (3- to 4-week-old) were used to establish primary cultures of RPE. Purity of the cultures was verified as described previously by immunodetection of RPE65, a known marker for RPE cells. ${ }^{17}$

\section{Senescence Assay}

Senescence assay was performed in $\mathrm{Hfe}^{+/+}$and $\mathrm{Hfe}^{-/-}$primary RPE cells during each passage using a commercially available senescence $\beta$ galactosidase staining kit (Cell Signaling Technology, Danvers, MA). Development of blue color after incubation with the reagents provided in the kit identifies senescent cells.

\section{Cell Cycle Analysis by Flow Cytometry}

Cells were fixed in $50 \%$ ethanol, treated with $0.1 \%$ sodium citrate, 1 $\mathrm{mg} / \mathrm{mL}$ RNase A and $50 \mu \mathrm{g} / \mathrm{mL}$ propidium iodide, and then subjected to fluorescence activated cell sorting (FACS Caliber; Becton Dickinson, Franklin Lakes, NJ) analysis to determine the percentage of cells in each phase of the cell cycle.

\section{Migration and Invasion Assay}

The migration of $\mathrm{Hfe}^{+/+}$and $\mathrm{Hfe}^{-/-}$RPE cells toward fetal bovine serum was measured using the QCM cell migration assay kit (Millipore, Billerica, MA). Serum-starved cells were allowed to migrate for 48 hours in a transwell in the presence of serum. After removing the cells on the top of the membrane filter, the inserts were stained with $0.1 \%$ crystal violet, washed, and dried. The crystal violet dye retained on the bottom of the filters (representing the cells that migrated to the underside of the membrane filter) was extracted with $10 \%$ acetic acid. The absorbance of the extract was measured at $560 \mathrm{~nm}$. Cell invasion assay was performed similarly using the QCM cell invasion assay kit. The inserts used in this assay were coated with ECMatrix (Millipore, Billerica, MA), representing the extracellular matrix. Serum-starved cells were allowed to invade the matrix for 48 hours in a transwell in the presence of serum. After removing the cells on the top of the membrane filter, the inserts were stained with $0.1 \%$ crystal violet, washed, and dried. The crystal violet dye retained on the bottom of the filters (representing the cells that invaded the matrix to the underside of the membrane filter) was extracted with $10 \%$ acetic acid. The absorbance of the extract was measured at $560 \mathrm{~nm}$.

\section{Real-Time Polymerase Chain Reaction}

RNA was isolated from wild type and $\mathrm{Hfe}^{-/-}$or $\mathrm{Hjv}^{-/}$primary RPE cells in passages three to five, and used for RT-PCR using GeneAmp RTPCR kit (Applied Biosystems Inc., Carlsbad, CA). Semi-quantitative PCR was performed using Taq polymerase kit (TaKaRa, Shiga, Japan). Realtime amplifications, using SYBR green detection chemistry, were run in triplicates on 96-well reaction plates. The expression levels of target mRNA was quantified by normalizing with the corresponding internal control (18S RNA). Each PCR experiment was repeated at least three times with similar results. The primers for real-time PCR (Table) were designed based on the sequence information available in GenBank (http://www.ncbi.nlm.nih.gov, provided in the public domain by the National Institutes of Health, Bethesda, MD) for mouse cDNAs.

\section{Western Blot}

RPE cells in passage four were washed with $0.01 \mathrm{M}$ PBS and lysed in ice cold lysis buffer $(50 \mathrm{mM}$ Tris-HCl, $\mathrm{pH} 7.4$, containing $1 \%$ Triton X-100, $10 \mathrm{mM}$ EDTA, $2 \mathrm{mM} \mathrm{Na}_{3} \mathrm{VO}_{4}, 0.5 \%$ deoxycholate, $10 \mathrm{mM}$ sodium pyrophosphate and $50 \mathrm{mM} \mathrm{NaF}$ ). Cells were sonicated for 15 to 20 seconds. The cell debris was removed by centrifugation at $10,000 \mathrm{~g}$ for 10 minutes at $4^{\circ} \mathrm{C}$. Protein concentration in the supernatant was determined using the bicinchoninic acid (BCA) assay (Thermo Fisher Scientific, Rockford, IL). The protein levels of survivin, acetylated, and total $\mathrm{H} 3$ and $\mathrm{H} 4$ in wild type and $\mathrm{Hfe}^{-/-}$RPE cells were assessed by Western blot using specific antibodies. Rabbit polyclonal antibody against survivin was obtained from Novus Biologicals (Littleton, CO). The primary antibodies used for the analysis of $\mathrm{H} 3$ and $\mathrm{H} 4$ acetylation were as follows: rabbit polyclonal anti-acetyl $\mathrm{H} 3$ and anti-acetyl $\mathrm{H} 4$, mouse monoclonal anti-H3, and rabbit polyclonal anti-H4 (Millipore). The secondary antibodies used for the detection of the positive bands were goat anti-rabbit IgG labeled with the infrared dye $800 \mathrm{CW}$ and goat anti-mouse IgG labeled with the infrared dye 680LT (LICOR Biosciences, Lincoln, NE). The intensities of the bands were quantified using the LICOR Odyssey instrument and the LICOR application software, version 3.0.

\section{Immunofluorescence Analysis}

Primary RPE cells were grown on 12-mm coverslips for 24 hours in 24well cell culture plates at $37^{\circ} \mathrm{C}$ in a $5 \% \mathrm{CO}_{2}$ incubator. Medium was removed and the cells were fixed in ice cold methanol for 10 minutes after air drying. Cells were then washed with $0.01 \mathrm{M} \mathrm{PBS} \mathrm{(pH} \mathrm{7.4)} \mathrm{and}$ blocked with $1 \times$ Power Block for 120 minutes. Cells were incubated overnight at $4^{\circ} \mathrm{C}$ with rabbit polyclonal anti-survivin (1:50 dilution). Sections were rinsed and incubated for 1 hour with goat anti-rabbit IgG coupled to Alexa Fluor 568 (Invitrogen, Grand Island, NY) at a dilution of 1:1000. Coverslips were mounted after staining with Hoechst (Invitrogen) (a nuclear stain) and sections were examined by epifluorescence using an Axioplan-2 microscope, equipped with an HRM camera and the Axiovision imaging program (Carl Zeiss, 
Thornwood, NY). Negative control cells were treated likewise, but in the absence of the primary antibodies.

\section{Glucose Uptake}

Sodium-coupled glucose transport is mediated by SGLTs and sodiumindependent transport is mediated by glucose transporters (GLUTs). We routinely measure the activity of GLUTs by cellular uptake oFf $\left[{ }^{3} \mathrm{H}\right]$ 3-O-methyl-D-glucose, which is a nonmetabolizable analog of glucose. Transport was measured using an uptake buffer in the presence or absence of sodium. The uptake buffer was $25 \mathrm{mM}$ Hepes/Tris ( $\mathrm{pH} 7.5$ ) containing $140 \mathrm{mM} \mathrm{NaCl}$ (presence of $\mathrm{Na}^{+}$) or $140 \mathrm{mM} \mathrm{N}$-methyl-Dglucamine (NMDG) chloride (absence of $\mathrm{Na}^{+}$) and $5.4 \mathrm{mM} \mathrm{KCl}, 1.8 \mathrm{mM}$ $\mathrm{CaCl}_{2}$, and $0.8 \mathrm{mM} \mathrm{MgSO}_{4}$. Uptake was initiated by the addition of 250 $\mu \mathrm{L}$ uptake buffer containing $50 \mu \mathrm{M}$ cold glucose, spiked with $1 \mu \mathrm{Ci}$ / well $\left[{ }^{3} \mathrm{H}\right]-3-O-m e t h y l$ D-glucose. Cells were incubated for 2 minutes at $37^{\circ} \mathrm{C}$, after which time the buffer was removed, and the cells were washed twice with ice cold uptake buffer. The cells were then solubilized with $0.5 \mathrm{~mL} 1 \%$ SDS/0.2 N NaOH, and radioactivity was determined by liquid scintillation counter. Protein was measured using the BCA assay (Thermo Fisher Scientific). The uptake measured in the presence of NMDG chloride was taken as the $\mathrm{Na}^{+}$-independent uptake whereas the difference between the uptake values obtained in the presence of NMDG chloride and $\mathrm{NaCl}$ was taken as the $\mathrm{Na}^{+}$-dependent uptake.

\section{Measurement of HDAC Activity}

The measurement of HDAC activity in lysates from $\mathrm{Hfe}^{+/+}$and $\mathrm{Hfe}^{-/-}$ primary RPE cells in passage four was carried out using a commercially available HDAC assay kit (Biovision, Milpitas, CA). This is a colorimetric assay.

\section{Xenograft in Nude Mice}

$\mathrm{Hfe}^{+/+}$and $\mathrm{Hfe}^{-/-}$primary RPE cells were injected subcutaneously on the back of BALB/c nude mice $\left(10 \times 10^{6}\right.$ cells/injection site). Mice were kept under observation for 3 months to analyze tumor progression.

\section{Statistics}

Statistical significance was determined by paired Student's $t$-test. A $P$ value less than 0.05 was taken as statistically significant.

\section{RESULTS}

\section{Senescence and Cell Cycle Changes in $\mathrm{Hfe}^{-/-}$RPE Cells}

Cellular senescence is an irreversible mechanism of cell cycle arrest in primary cultured cells and has been demonstrated to restrict tumorigenesis in vivo. ${ }^{21,22}$ We reported previously that $\mathrm{Hfe}^{-/-} \mathrm{RPE}$ cells are hyperproliferative and continue to grow even after the fifth passage, unlike the $\mathrm{Hfe}^{+/+} \mathrm{RPE}$ cells that do not proliferate after passage five. ${ }^{17}$ In order to determine if there is any difference in the senescence pattern, we compared the activity of senescence-specific $\beta$-galactosidase between $\mathrm{Hfe}^{+/+}$and $\mathrm{Hfe}^{-/-}$RPE cells. There was no difference between the cells of the two genotypes in the number of senescent cells until passage three. However, in passages four and five, there was a significant increase in the number of senescent cells in $\mathrm{Hfe}^{+/+} \mathrm{RPE}$ cells compared with $\mathrm{Hfe}^{-/-} \mathrm{RPE}$ cells. These data indicate that while $\mathrm{Hfe}^{+/+}$cells undergo senescence after the third passage, $\mathrm{Hfe}^{-/-}$cells do not become senescent and continue to proliferate (Fig. 1A). Also, using FACS analysis, we found that in passages four and five there is a small, but significant, increase in the number of cells in the G2/
TABLE. The following Primers Were Used for Real-Time PCR

\begin{tabular}{|c|c|}
\hline \multicolumn{2}{|l|}{ Survivin } \\
\hline $\begin{array}{l}\text { Forward: } \\
\text { Reverse: }\end{array}$ & $\begin{array}{l}\text { 5'-ATCCACTGCCCTACCGAGAA-3' } \\
\text { 5'-CTTGGCTCTCTGTCTGTCCAGTT-3' }\end{array}$ \\
\hline \multicolumn{2}{|c|}{ Hexokinase II } \\
\hline $\begin{array}{l}\text { Forward: } \\
\text { Reverse: }\end{array}$ & $\begin{array}{l}\text { 5'-TTTTGCCAAGCGTCTCCATAAG-3' } \\
5^{\prime}-\text { GCCGCTGCCATCCTCAGAGCGGA-3' }\end{array}$ \\
\hline \multicolumn{2}{|l|}{ Slc6a14 } \\
\hline $\begin{array}{l}\text { Forward: } \\
\text { Reverse: }\end{array}$ & $\begin{array}{l}\text { 5'-GCTTCATCCGAGAACTTCCATGTTG-3' } \\
\text { 5'-TTACTATTGGTGTTCTGCTACAGTTTT-3' }\end{array}$ \\
\hline \multicolumn{2}{|l|}{ Slc5a8 } \\
\hline $\begin{array}{l}\text { Forward: } \\
\text { Reverse: }\end{array}$ & $\begin{array}{l}\text { 5'-TGCCATTTCCTTATGGGTAGG-3' } \\
\text { 5'-AGTGGAGTCCTTTCCGCATTA-3' }\end{array}$ \\
\hline \multicolumn{2}{|l|}{ SGLT1 } \\
\hline $\begin{array}{l}\text { Forward: } \\
\text { Reverse: }\end{array}$ & $\begin{array}{l}\text { 5'-TCTGTAGTGGCAAGGGGAAG-3' } \\
\text { 5'-ACAGGGCTTCTGTGTCTTGG-3' }\end{array}$ \\
\hline \multicolumn{2}{|l|}{ GLUT1 } \\
\hline $\begin{array}{l}\text { Forward: } \\
\text { Reverse: }\end{array}$ & $\begin{array}{l}\text { 5'-AGTGTATCCTGTTGCCCTTCT-3' } \\
\text { 5'-CATCGGCTGTCCCTCGAAGC-3' }\end{array}$ \\
\hline \multicolumn{2}{|l|}{ GLUT2 } \\
\hline $\begin{array}{l}\text { Forward: } \\
\text { Reverse: }\end{array}$ & $\begin{array}{l}\text { 5'-CTGGGTCTGCAATTTTGTCA-3' } \\
\text { 5'-TGTAAACAGGGTGAAGACCA-3' }\end{array}$ \\
\hline \multicolumn{2}{|l|}{ GLUT3 } \\
\hline $\begin{array}{l}\text { Forward: } \\
\text { Reverse: }\end{array}$ & $\begin{array}{l}\text { 5'-GACTGCTTCTGAGTGCTGCTA-3' } \\
\text { 5'-CATTGGCGATCTGGTCAACC-3' }\end{array}$ \\
\hline \multicolumn{2}{|l|}{ GLUT4 } \\
\hline $\begin{array}{l}\text { Forward: } \\
\text { Reverse: }\end{array}$ & $\begin{array}{l}\text { 5'-GTCCTCCTGCTTGGCTTCTT-3' } \\
\text { 5'-AGCTGAGATCTGGTCAAACG-3' }\end{array}$ \\
\hline \multicolumn{2}{|l|}{$H D A C 1$} \\
\hline $\begin{array}{l}\text { Forward: } \\
\text { Reverse: }\end{array}$ & $\begin{array}{l}\text { 5'-ATTCCTGCGTTCTATTCGCCCAGA-3' } \\
\text { 5'-TTAGCAGTTCCAGGATGGCCAAGA-3' }\end{array}$ \\
\hline \multicolumn{2}{|l|}{$H D A C 2$} \\
\hline $\begin{array}{l}\text { Forward: } \\
\text { Reverse: }\end{array}$ & $\begin{array}{l}\text { 5'-GACATATGAGACTGCAGTTGC-3' } \\
\text { 5'-ACCTCCTTCTCCTTCATCCTC-3' }\end{array}$ \\
\hline \multicolumn{2}{|l|}{$H D A C 3$} \\
\hline $\begin{array}{l}\text { Forward: } \\
\text { Reverse: }\end{array}$ & $\begin{array}{l}\text { 5'-TGATGACCAGAGTTACAAGCAC-3' } \\
\text { 5'-GGGCAACATTTC GGACAG-3' }\end{array}$ \\
\hline \multicolumn{2}{|l|}{ HDAC4 } \\
\hline $\begin{array}{l}\text { Forward: } \\
\text { Reverse: }\end{array}$ & $\begin{array}{l}\text { 5'-GGAACTCCTAGCACTGAAACAGAAG-3' } \\
\text { 5'-TTCATGCAACTGTGCCTCATG-3' }\end{array}$ \\
\hline \multicolumn{2}{|l|}{ HDAC5 } \\
\hline $\begin{array}{l}\text { Forward: } \\
\text { Reverse: }\end{array}$ & $\begin{array}{l}\text { 5'-TATTCACCATGGCAACGGC-3' } \\
\text { 5'-CTGGAAAGAAGTTCCCGTTGTC-3' }\end{array}$ \\
\hline \multicolumn{2}{|l|}{ HDAC6 } \\
\hline $\begin{array}{l}\text { Forward: } \\
\text { Reverse: }\end{array}$ & $\begin{array}{l}\text { 5'-TGCTGTGACCCCACTATCC-3' } \\
\text { 5'-TTCTGGTGGGCGATAGCGTTCTT-3' }\end{array}$ \\
\hline \multicolumn{2}{|l|}{ DNMT1 } \\
\hline $\begin{array}{l}\text { Forward: } \\
\text { Reverse: }\end{array}$ & $\begin{array}{l}\text { 5'-CCAAGCTCCGGACCCTGGATGTGT-3' } \\
\text { 5'-CGAGGCCGGTAGTAGTCACAGTAG-3' }\end{array}$ \\
\hline \multicolumn{2}{|l|}{ DNMT3a } \\
\hline $\begin{array}{l}\text { Forward: } \\
\text { Reverse: }\end{array}$ & $\begin{array}{l}\text { 5'-GCACCTATGGGCTGCTGCGAAGACG-3' } \\
\text { 5'-CTGCCTCCAATCACCAGGTCGAATG-3' }\end{array}$ \\
\hline \multicolumn{2}{|l|}{ DNMT3b } \\
\hline $\begin{array}{l}\text { Forward: } \\
\text { Reverse: }\end{array}$ & $\begin{array}{l}\text { 5'-CAAGGAGGGCGACAACCGTCCATT-3' } \\
\text { 5'-TGTTGGACACGTCCGTGTAGTGAG-3' }\end{array}$ \\
\hline \multicolumn{2}{|l|}{$18 S$} \\
\hline $\begin{array}{l}\text { Forward: } \\
\text { Reverse: }\end{array}$ & $\begin{array}{l}\text { 5'-CGGCTACCACATCCAAGGAA-3' } \\
\text { 5'-GCTGGAATTACCGCGGCT-3' }\end{array}$ \\
\hline
\end{tabular}



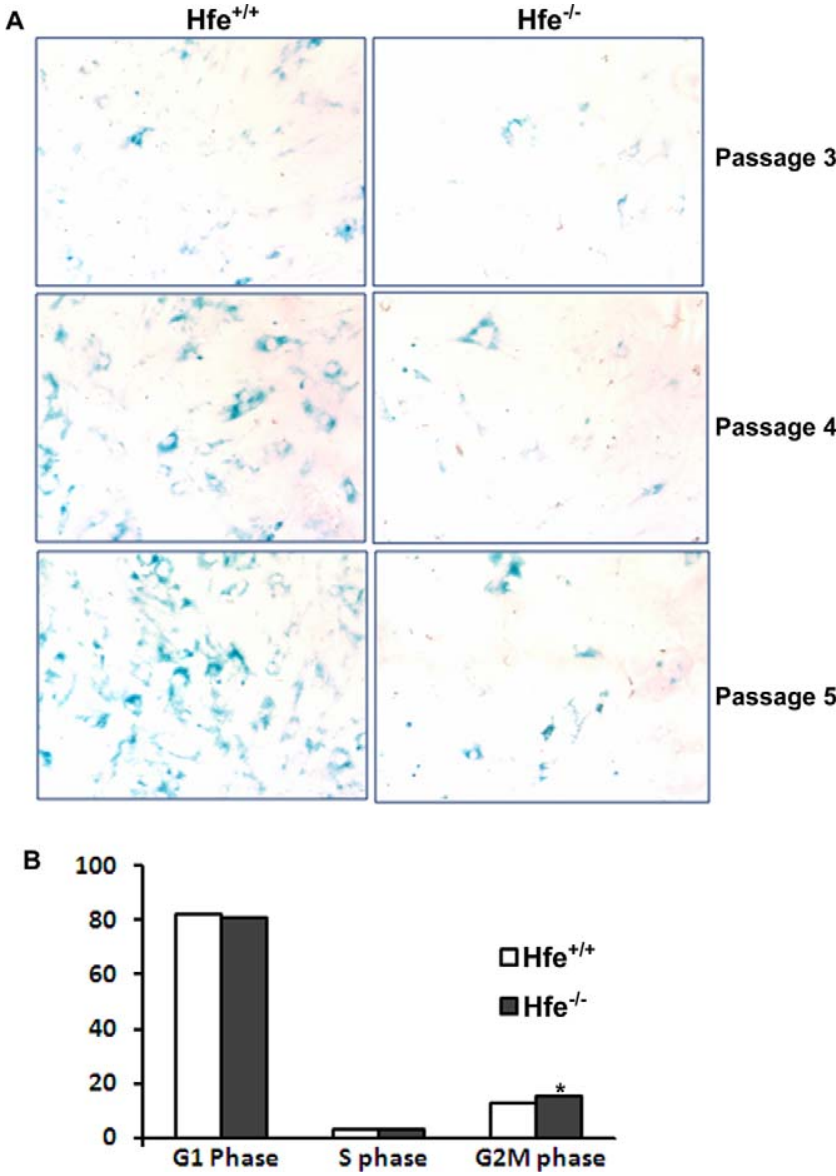

Figure 1. Senescence and cell cycle changes in $\mathrm{Hfe}^{-/-}$primary RPE cells. (A) Senescence assay with $\mathrm{Hfe}^{+/+}$and $\mathrm{Hfe}^{+/+}$primary RPE cells. Blue color indicates senescent cells. (B) Flow cytometric analysis of $\mathrm{Hfe}^{+/+}$and $\mathrm{Hfe}^{-/-}$primary RPE cells stained with propidium iodide. Bar diagram is a representation of the percentage of cells in $G_{0} / G_{1}, S$, and $G_{2} / M$ phases. ${ }^{*} P<0.05$. The experiments were repeated four times.

M phase in $\mathrm{Hfe}^{-/-}$cells compared with $\mathrm{Hfe}^{+/+}$RPE cells (Fig. 1B), indicating that more number of cells undergo cell division in $\mathrm{Hfe}^{-/-}$cells than in $\mathrm{Hfe}^{+/+}$RPE cells.

\section{Upregulation of Survivin in $\mathrm{Hfe}^{-/}$RPE Cells}

Survivin is a member of the inhibitor of apoptosis proteins (IAP) family of molecules that specifically inhibit caspase three, seven, and nine and, thereby, prevent apoptosis. ${ }^{23,24}$ We found that survivin expression was upregulated in $\mathrm{Hfe}^{-/-}$primary RPE cells at mRNA and protein levels (Figs. 2A, 2B). Immunofluorescence analysis also confirmed this upregulation (Fig. 2C).

\section{Migratory and Invasive Properties of $\mathrm{Hfe}^{-/-}$RPE Cells}

The ability of a cancer cell to undergo migration and invasion allows it to not only move to the surrounding tissues, but also to metastasize to distant organs. In the present study, we grew $\mathrm{Hfe}^{+/+}$and $H \mathrm{fe}^{-/-}$RPE cells in serum-free medium in the upper chamber of transwells, and stained the cells that migrated to the underside of the membrane facing the lower chamber exposed to serum (Fig. 3A). The staining was then quantified by dissolving the dye in $10 \%$ acetic acid (Figs. 3B, 3C). We found that $\mathrm{Hfe}^{-/-}$cells exhibited a much greater migratory
A

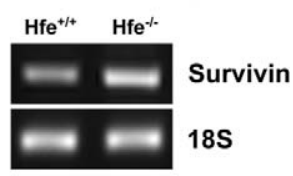

B
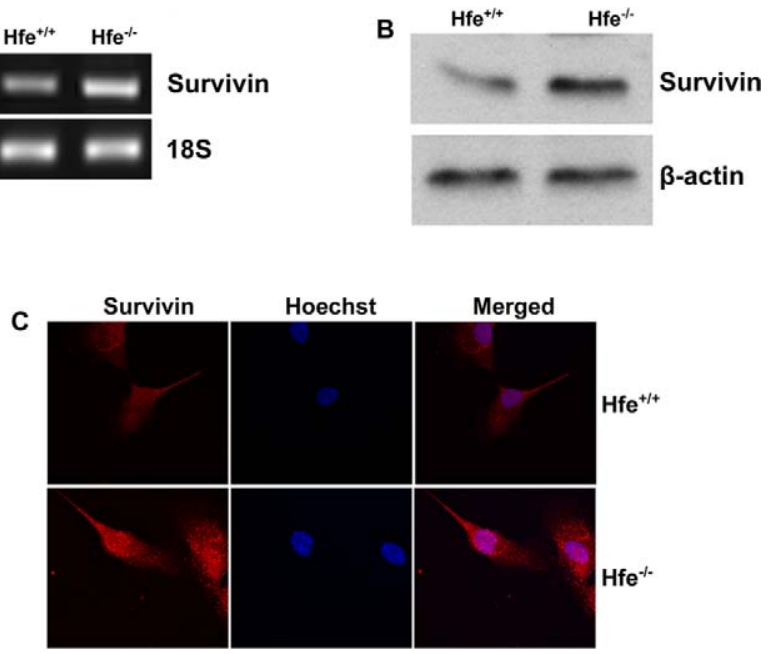

FIGURE 2. Upregulation of survivin in $\mathrm{Hfe}^{-/-}$primary RPE cells. (A) RTPCR analysis of survivin mRNA transcripts in $\mathrm{Hfe}^{+/+}$and $\mathrm{Hfe}^{-/-}$primary RPE cells. 18S RNA was used as an internal control. (B) Western blot for survivin protein in $\mathrm{Hfe}^{+/+}$and $\mathrm{Hfe}^{-/-}$primary RPE cells. $\beta$-Actin was used as a loading control. (C) Immunostaining for survivin in $\mathrm{Hfe}^{+/+}$ and $\mathrm{Hfe}^{-/}$primary RPE cells.

capability than $\mathrm{Hfe}^{+/+}$cells. Interestingly, there was no difference in the invasive property between the cells of the two genotypes.

\section{Increase in Glucose Uptake by $\mathrm{Hfe}^{-/}$RPE Cells}

Cancer cells alter their metabolism in order to support their rapid proliferation. Sodium-coupled glucose transporters (SGLTs) and facilitative GLUTs are upregulated to increase the uptake of glucose by cancer cells. ${ }^{25-27}$ We found that SGLT1, GLUT1, and GLUT3 were upregulated at mRNA level in $\mathrm{Hfe}^{-/-} \mathrm{RPE}$ cells (Fig. 4A). To determine if there is a functional increase in glucose uptake by $H \mathrm{fe}^{-/-}$RPE cells compared with $\mathrm{Hfe}^{+/+}$cells, we performed $\left[{ }^{3} \mathrm{H}\right]-3$-O-methyl D-glucose uptake studies. Glucose gets metabolized inside the cells quickly and, hence, we used $\left[{ }^{3} \mathrm{H}\right]$-3-O-methyl D-glucose, a glucose derivative that is nonmetabolizable, to measure the function of glucose transporters. In the absence of sodium, there was a significant increase in glucose uptake by $\mathrm{Hfe}^{-/-}$cells irrespective of the passage number used (Fig. 4B), indicating an increase in the activity of facilitative glucose transporters (GLUT1 and GLUT3). There was also an increase in glucose uptake by $\mathrm{Hfe}^{-{ }^{-}}$RPE cells when measured in the presence of sodium. When the sodium-dependent uptake was analyzed separately (i.e., uptake in the presence of sodium minus uptake in the absence of sodium), the uptake was higher in $\mathrm{Hfe}^{-/-}$RPE cells than in $\mathrm{Hfe}^{+/+}$cells (Fig. 4C), indicating an increase in the activity of SGLT1 in $\mathrm{Hfe}^{-/-}$RPE cells. Glucose is metabolized in cancer cells by hexokinase II, the first enzyme in the glycolytic pathway; this particular isoenzyme is upregulated in some cancers. ${ }^{28}$ However, we did not find any change in the mRNA levels of hexokinase II between the RPE cells of the two genotypes (Fig. 5A).

\section{Differential Expression of Slc6a14 and Slc5a8 in $\mathrm{Hfe}^{-/}$RPE Cells}

Slc6a14 is an amino acid transporter with broad substrate selectivity. Tumor cells have an increased requirement for essential amino acids as well as arginine and glutamine to support their rapid growth and hence this transporter is 


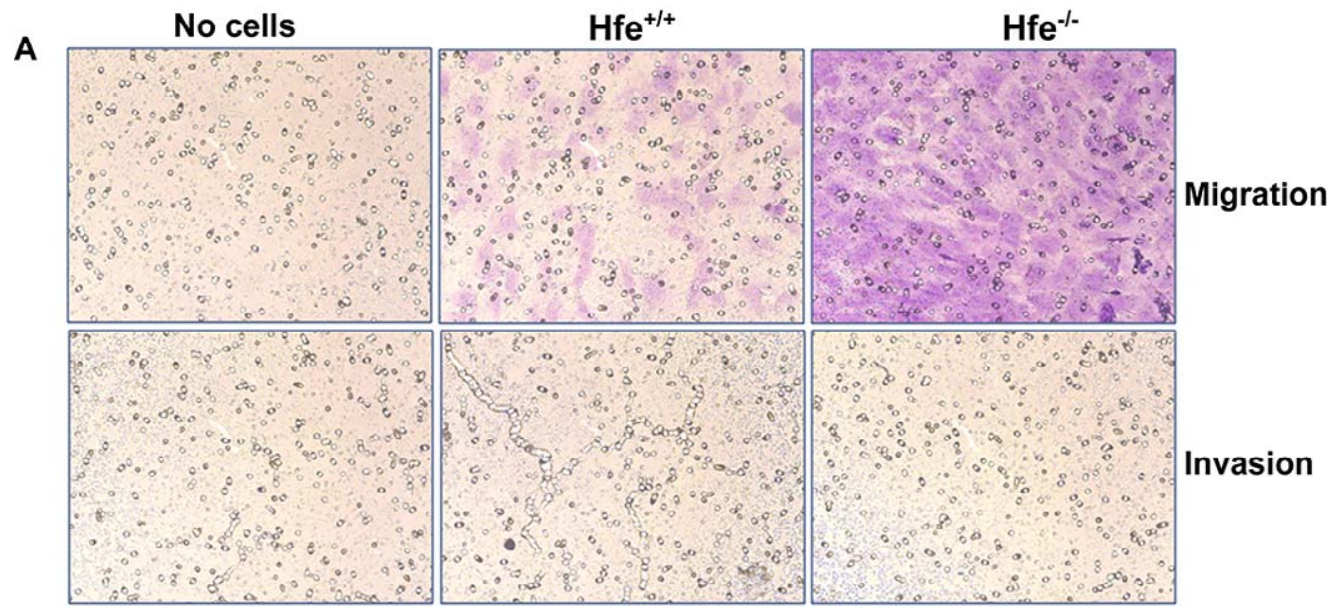

B

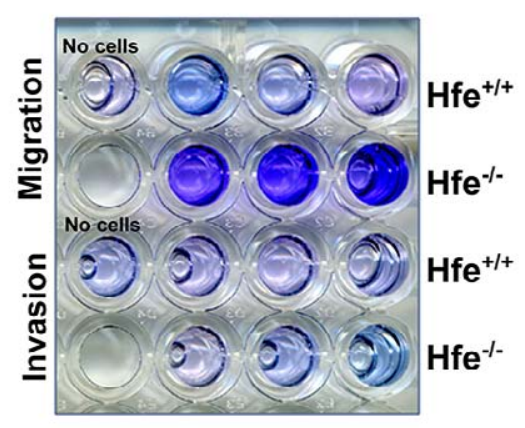

C

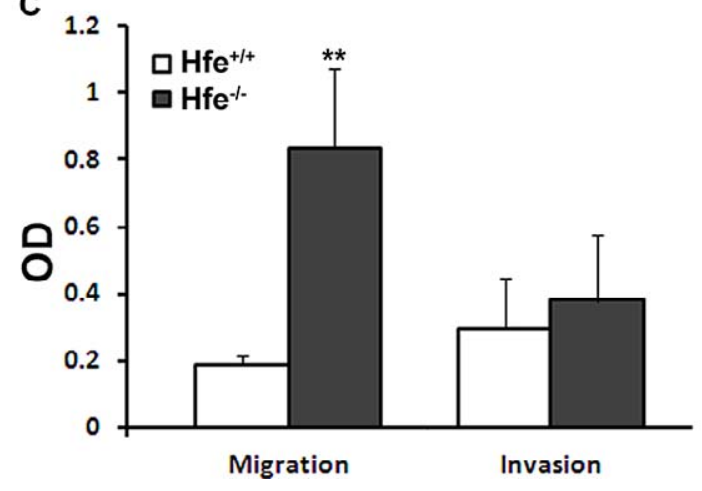

Figure 3. Migration and invasion assays with $H f e^{+/+}$and $H f e^{-/-}$primary RPE cells. (A) Representative micrograph images of cells stained after migration and invasion assays in $\mathrm{Hfe}^{+/+}$and $\mathrm{Hfe}^{-/}$primary RPE cells at passage four. Far left panel shows the well where no cells were seeded, middle panel represents $H f^{+/+}$cells and the far right panel Hfe ${ }^{-/-}$primary RPE cells. (B) The cells that moved to the trans side of the filter were stained, and the dye was dissolved in $10 \%$ acetic acid and collected in 96-well plates. (C) The optical density (OD) of the dye extract was determined at $560 \mathrm{~nm}$. ${ }^{* * *} P<0.01$. The experiments were repeated thrice with similar results.

upregulated in many tumors. ${ }^{29,30}$ We found that Slc6a14 was upregulated in $\mathrm{Hfe}^{-/-} \mathrm{RPE}$ cells compared with $\mathrm{Hfe}^{+/+} \mathrm{RPE}$ cells (Fig. 5B). SLC5A8 encodes a sodium-coupled monocarboxylate transporter for endogenous monocarboxylates such as butyrate and pyruvate. SLC5A8 is a tumor suppressor, and epigenetic silencing of $S L C 5 A 8$ involving promoter hypermethylation is seen in many cancers. ${ }^{31,32}$ In this study, we found that Slc5a8 was downregulated significantly in $\mathrm{Hfe}^{-/-}$ RPE cells compared with wild type cells (Fig. 5B).

\section{Epigenetic Modifications in $\mathrm{Hfe}^{-/-}$RPE Cells}

HDACs are key enzymes that deacetylate histones, thereby regulating important cell processes such as cell-cycle progression and apoptosis. Increase in HDAC activity is seen in a variety of cancers. ${ }^{33,34}$ We found upregulation of HDAC 1-3 mRNA in $H f e^{-/}$RPE cells (Fig. 6A). The total HDAC enzyme activity was also higher in $\mathrm{Hfe}^{-{ }^{-}-} \mathrm{RPE}$ cells (Fig. 6B). Although HDAC activity was higher in $H f e^{-/-}$RPE cells, unexpectedly the ratios of acetylated $\mathrm{H} 3$ and $\mathrm{H} 4$ levels to $\beta$-actin were also higher in $\mathrm{Hfe}^{-/-} \mathrm{RPE}$ cells than in $\mathrm{Hfe}^{+/+} \mathrm{RPE}$ cells. Interestingly, the total $\mathrm{H} 3$ and $\mathrm{H} 4$ protein levels also increased in $\mathrm{Hfe}^{-/-} \mathrm{RPE}$ cells (Fig. 6C). However, the ratios of acetyl $\mathrm{H} 3$ and $\mathrm{H} 4$ to total $\mathrm{H} 3$ and $\mathrm{H} 4$, respectively, were lower in $\mathrm{Hfe}^{-/}$RPE cells compared with the $\mathrm{Hfe}^{+/+}$cells as expected to concur with the increase in HDAC activity (Fig. 6D).
DNA methyltransferase (DNMT) family of enzymes catalyzes the transfer of the methyl group from S-adenosylmethionine to DNA. Three active DNMTs have been identified in mammals, namely, DNMT1, DNMT3a, and DNMT3b. DNMTs are upregulated in many cancers resulting in hypermethylation of tumor suppressor genes and their consequent inactivation. ${ }^{35}$ We found that $\mathrm{Hfe}^{-/-} \mathrm{RPE}$ cells upregulate DNMT1 and DNMT3a at mRNA level (Fig. 7A). It has been well established that silencing of SLC5AB is associated with DNA methylation and that treatment of cancer cells with DNA-demethylating agents re-actives SLC5A8 expression. ${ }^{31,32}$ Therefore, we treated $\mathrm{Hfe}^{+/+}$and $\mathrm{Hfe} \mathrm{e}^{-/-}$RPE cells with 5-aza2-deoxycytidine (5-Azadc), a DNA-demethylating agent, and monitored Slc5a8 expression (Fig. 7B). Treatment with 5Azadc did not alter Slc5a8 expression in $\mathrm{Hfe}^{+/+}$RPE cells whereas it re-activated Slc5a8 expression in $\mathrm{Hfe}^{-/-}$RPE cells similar to cancer cells.

\section{Tumor Phenotype in $\mathrm{Hjv}^{-/}$Primary RPE cells}

$\mathrm{Hjv}$ is another important iron-regulatory protein that is expressed extensively in different cell types of retina. ${ }^{14}$ We have already reported hypertrophy and hyperproliferation in RPE of both Hfe and Hjv knockout mouse models of hemochromatosis. ${ }^{17,18}$ To confirm that the molecular and biochemical changes found in $\mathrm{Hfe}^{-/-}$RPE cells hold true also in 

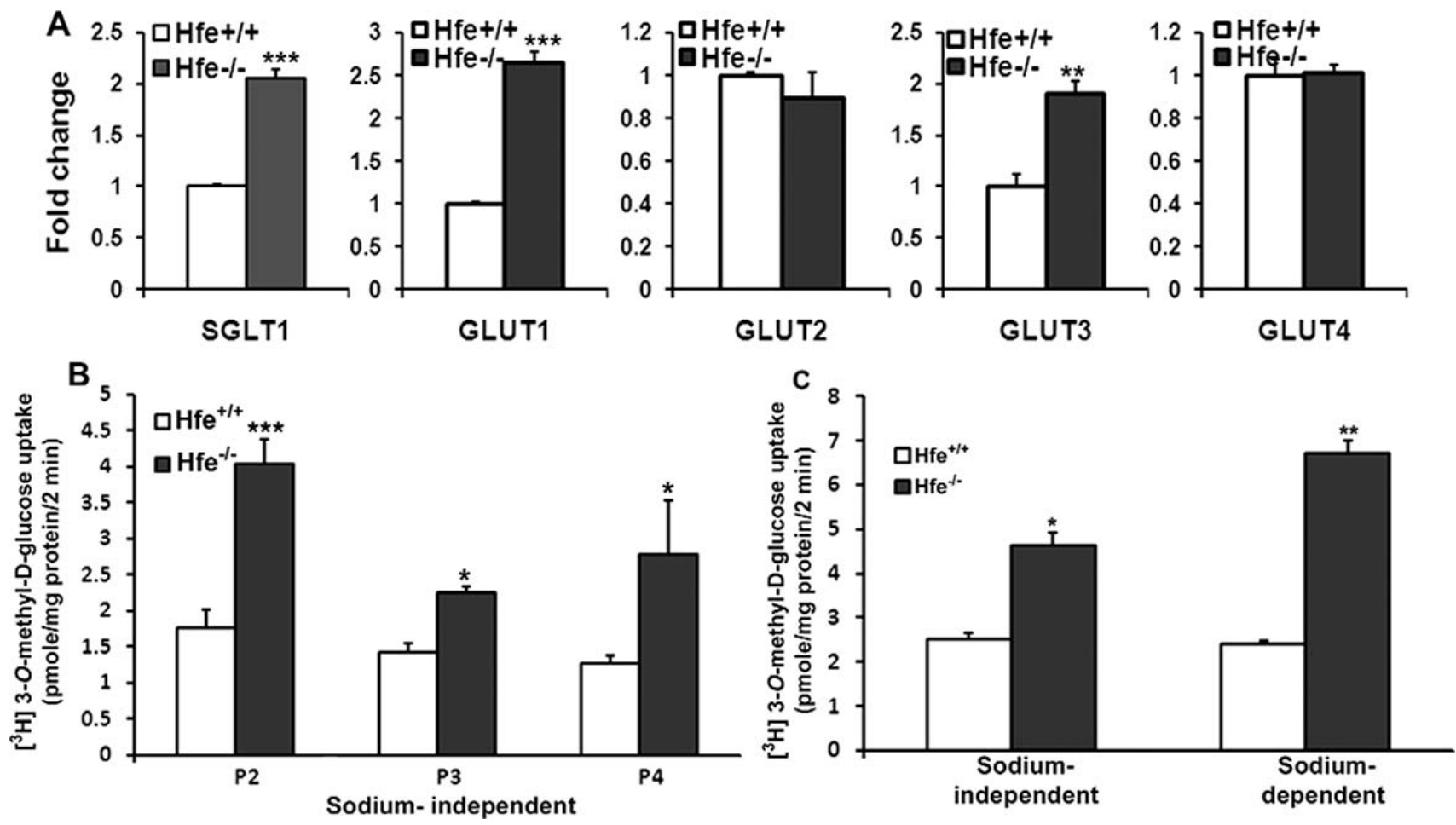

FiguRE 4. Upregulation of glucose transporters in $\mathrm{Hfe}^{-/}$primary RPE cells. (A) Real-time PCR analysis showing mRNA levels of sodium-coupled glucose transporter SGLT1 and facilitative glucose transporters (GLUT1-4) in $\mathrm{Hfe}^{+/+}$and $\mathrm{Hfe}^{-/-}$RPE cells from passage three or four. (B) Uptake of $\left[{ }^{3} \mathrm{H}\right]-3-\mathrm{O}$-methyl-D-glucose was measured in passage two, three, and four (P2, P3, and P4) in $\mathrm{Hfe}^{+/+}$and $\mathrm{Hfe}^{-/-} \mathrm{RPE}$ cells. Uptake was measured for 2 minutes at $37^{\circ} \mathrm{C}$ in the absence of $\mathrm{Na}^{+}$with $1 \mu \mathrm{Ci} /$ well of $\left[{ }^{3} \mathrm{H}\right] 3-O$-methyl-D-glucose and $50-\mu \mathrm{M}$ unlabeled glucose. NMDG chloride was used to substitute for $\mathrm{NaCl}$ in the uptake medium. (C) $\mathrm{Na}^{+}$-independent and $\mathrm{Na}^{+}$-dependent uptakes of $\left[{ }^{3} \mathrm{H}\right]$-3-O-methyl-D-glucose were also measured in $\mathrm{Hfe}^{+/+}$and $H \mathrm{fe}^{-/-}$RPE cells (P2). ${ }^{*} P<0.05 ;{ }^{* *} P<0.01 ;{ }^{* * *} P<0.001$.

RPE cells from another mouse model of iron overload, we checked the expression levels of GLUTs, HDACs, and DNMTs in $\mathrm{Hjv}^{-/}$mouse primary RPE cells. We found that GLUT1, GLUT3, and SGLT1 were significantly upregulated in $\mathrm{Hjv}^{-/-}$ RPE cells (Fig. 8A). Similarly, we found an upregulation in the expression of HDAC1, 2, 3, and 6 in $\mathrm{Hjv}^{-/-}$RPE cells. However, there was no significant change in the levels of HDAC4 and 5 (Fig. 8B). We also found a robust upregulation of DNMT1 and $3 \mathrm{a}$ in $\mathrm{Hjv}^{-/-}$RPE cells (Fig. 8C).

\section{Inability of $\mathrm{Hfe}^{-/-}$RPE Cells to Form Tumors in Nude Mice}

Since deletion of Hfe in RPE cells induces many biochemical and genetic features that are characteristic of tumor cells, we were interested to find out if these alterations are sufficient for
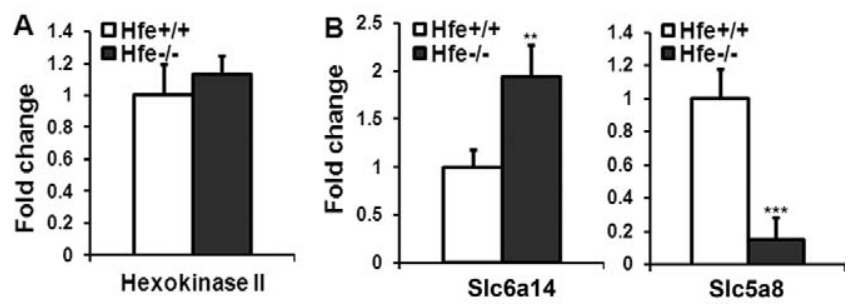

Figure 5. Differential expression of hexokinase II, Slc6a14, and Slc5a8 in $\mathrm{Hfe}^{+/+}$and $\mathrm{Hfe}^{-/-}$primary RPE cells. (A) Real-time PCR analysis of mRNA transcripts specific for hexokinase II in $\mathrm{Hfe}^{+/+}$and $\mathrm{Hfe}^{-/-} \mathrm{RPE}$ cells (P3). (B) Real-time PCR analysis of mRNA transcripts specific for Slc6a14 and Slc5a8 in $\mathrm{Hfe}^{+/+}$and $\mathrm{Hfe}^{-/-}$RPE cells. 18S RNA was used as an internal control. ${ }^{* *} P<0.01 ;{ }^{* * *} P<0.001$. malignant transformation. Therefore, we examined the ability of $\mathrm{Hfe}^{-/}$RPE cells to form tumors when xenografted into athymic nude mice. We found no evidence of tumor formation even after 3 months following subcutaneous injection of these cells in nude mice (data not shown). This indicates that though $H \mathrm{fe}^{-/}$RPE cells exhibit several characteristic features of tumor cells, they are not malignant and are unable to grow into tumors.

\section{Discussion}

Our previous studies show clear evidence of focal areas of RPE hyperproliferation in hemochromatosis mouse models of iron overload. ${ }^{17,18}$ We also found that primary cultures of RPE from these mouse models are hyperproliferative in vitro. We carried out the present study to understand the molecular aspects of this phenotype. In each cycle of cell division, chromosomes replicate in S-phase and then segregate to create two genetically identical daughter cells in M-phase. Cell cycle checkpoints signal abnormalities in critical events such as DNA replication and chromosome segregation. Any dysregulation in these checkpoints may result in unrestricted cell cycle and hyperproliferative phenotype. The present findings indicate that $\mathrm{Hfe}^{-/-} \mathrm{RPE}$ cells showed a small, but significant, increase in the percentage of cells in the Gap 2/mitosis phase (G2M) compared with $H f e^{+/+}$cells. This indicated that deletion of Hfe in RPE cells enhances the cell proliferation rate, but only to a small extent. However, there was a marked decrease in senescence and increase in the expression of the anti-apoptotic protein survivin in $\mathrm{Hfe}^{-/-}$cells compared with wild type cells. Survivin is known to be a multifunctional protein that can regulate cell division, enhance angiogenesis 

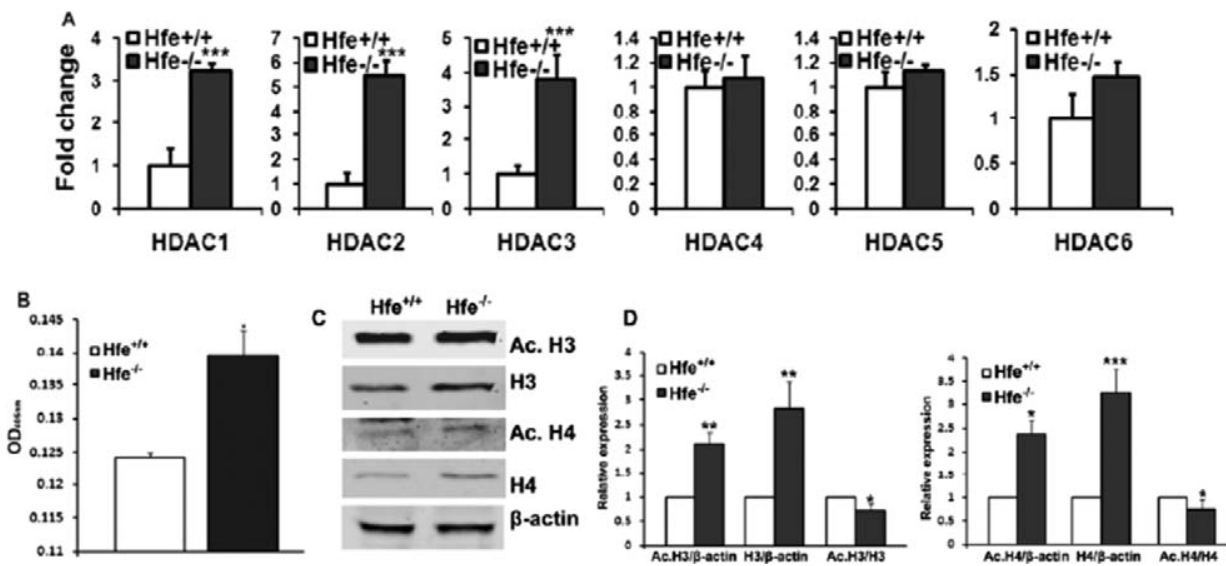

Figure 6. Epigenetic changes in $\mathrm{Hfe}^{-/-}$primary RPE cells. (A) Real-time PCR analysis of HDAC1, 2, 3, 4, 5, and 6 mRNA levels in $\mathrm{Hfe}^{+/+}$and $\mathrm{Hfe}^{-/}$ primary RPE cells (P4). (B) Total HDAC activity was measured in $\mathrm{ffe}^{+/+}$(WT) and $\mathrm{Hfe}^{-/-}$(KO) primary RPE cells from P4. (C) Western blot analysis showing acetyl- $\mathrm{H} 3$ and $\mathrm{H} 4$, total $\mathrm{H} 3$ and $\mathrm{H} 4$ with $\beta$-actin as a loading control. (D) Bar diagram showing the ratios of intensity of acetyl $\mathrm{H} 3$ and $\mathrm{H} 4$ to total $\mathrm{H} 3$ and $\mathrm{H} 4$ and the ratio of intensity of acetyl $\mathrm{H} 3$ and $\mathrm{H} 4$ to $\beta$-actin. ${ }^{*} P<0.05 ;{ }^{* * *} P<0.01 ;{ }^{* * * *} P<0.001$.

and inhibit apoptosis. ${ }^{36}$ Survivin is upregulated in many cancers and is hardly expressed in terminally differentiated tissues. ${ }^{37}$ Due to its significant role as an inhibitor of apoptotic cell death, we believe that the upregulation of survivin expression observed in $H f^{-/-}$primary RPE cells protects the cells from apoptosis. Thus, it appears that the increased proliferation rate observed in $\mathrm{Hfe}^{-{ }^{-1}}$ RPE cells is mostly due to changes in the senescence rate and apoptosis, with only a small contribution from increased cell division.

To spread within the tissues, tumor cells use migration mechanisms that are not identical but are similar to those that occur in normal cells during physiological processes such as embryonic development, wound healing, and immune-cell trafficking. ${ }^{38}$ Substantial increase in the migration of $\mathrm{Hfe}^{-/-}$ RPE cells compared with the control cells observed in the present study demonstrates the propensity of the $\mathrm{Hfe}^{-/-} \mathrm{RPE}$ cells toward tumor phenotype. Cells undergo genetic, metabolic, and epigenetic alterations to become cancerous. In the present study, we found many of these changes in $\mathrm{Hfe}^{-/-} \mathrm{RPE}$ cells. Slc5a8 is a well known tumor suppressor silenced in many tumors and is downregulated in $\mathrm{Hfe}^{-1-} \mathrm{RPE}$ cells. Similarly, Slc6a14, a tumor promoter, is upregulated in $\mathrm{Hfe}^{-/-}$ RPE cells, indicating that these genetic modifications are likely to play a significant role in the hyperproliferative phenotype. It has been known for decades that cancer cells require high levels of glucose to fulfill their energy requirements. Our findings that $\mathrm{Hfe}^{-/-}$RPE cells have increased levels of glucose uptake and utilization confirm the metabolic changes that occur in these cells that are congruent with those found in tumor cells

DNA methylation, specifically silencing of tumor-suppressor genes by promoter hypermethylation, has been one of the most widely studied epigenetic modifications in human cancers. ${ }^{35}$ However, in recent years there has been a significant understanding in our knowledge about the involvement of abnormal histone modifications, especially with regard to the acetylation status in cancer development. Acetylation levels of histone are the result of a balance between the activities of HATs and HDACs. ${ }^{39}$ The presence of acetylated lysine in histones is associated with a relaxed chromatin and active gene transcription, while the deacetylation of lysine residues results in a condensed chromatin and transcriptional gene inactivation. ${ }^{33,34}$ We not only found an increase in the HDAC activity in $\mathrm{Hfe}^{-/-} \mathrm{RPE}$ cells, but also found that histone protein levels are upregulated in these cells. Eukaryotic chromosome replication requires synthesis of not only DNA, but also histone proteins needed to package the newly replicated DNA into a chromatin. In most cells, the synthesis of histones is tightly coupled with the rate of DNA replication. Since $\mathrm{Hfe}^{-/-}$RPE cells proliferate faster than control cells, it is plausible that total histone levels increase in $\mathrm{Hfe}^{-/}$cells to package the replicating DNA. Other studies have shown that overexpression of integrated genes encoding histones $\mathrm{H} 3 / \mathrm{H} 4$, but not $\mathrm{H} 2 \mathrm{~A} / \mathrm{H} 2 \mathrm{~B}$, extends the median life span of normal cells by $30 \% .{ }^{40}$ Thus, increase in the total $\mathrm{H} 3$ and $\mathrm{H} 4$ histone levels may also play a role in reducing the senescence in $\mathrm{Hfe}^{-/-}$RPE cells.

Thus, the present study shows convincingly that deletion of $H f e$ in RPE cells leads to a broad spectrum of biochemical and genetic changes resulting in features that are characteristic of tumor cells. These changes, including increased glucose uptake, overexpression of the amino acid transporter Slc6a14, increased expression of HDACs and DNMTs, overexpression of the anti-apoptotic protein survivin, and decreased senescence, underlie the hyperproliferative phenotype observed in these cells. A similar phenomenon is also seen in RPE cells upon deletion of $H j v$, another iron-regulatory protein. In humans as well as in mice, deletion of $\mathrm{Hfe}$ or $\mathrm{Hjv}$ leads to abnormal

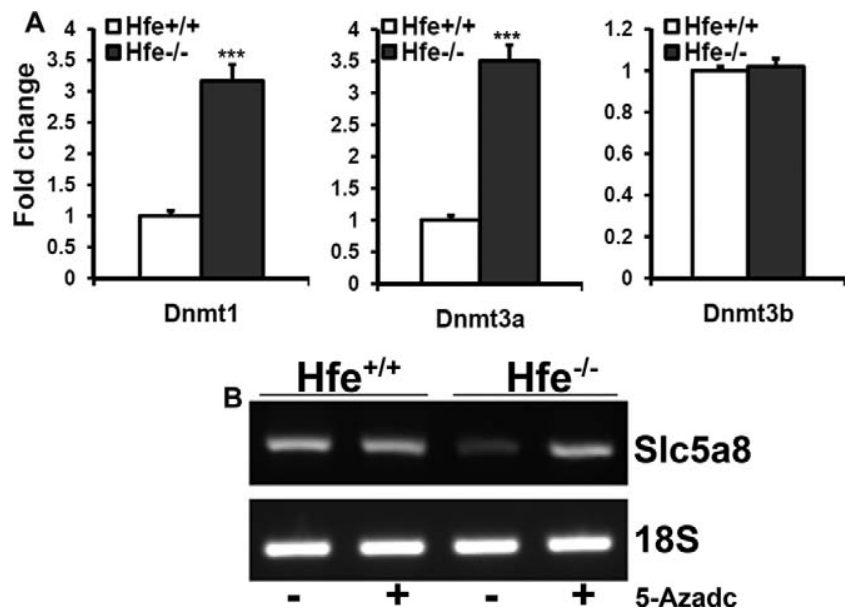

Figure 7. Expression analysis of DNMTs in $\mathrm{Hfe}^{+/+}$and $\mathrm{Hfe}^{-/-} \mathrm{RPE}$ cells. (A) Real-time PCR analysis for the levels of DNMT1, DNMT3a, and DNMT3b mRNAs in $\mathrm{Hfe}^{+/+}$and $\mathrm{Hfe}^{-/-}$RPE cells (P3). (B) RT-PCR analysis for the levels of Slc5a8 mRNA in $\mathrm{Hfe}^{+/+}$and $\mathrm{Hfe}^{-/-}$RPE cells, which had been treated with 5-aza-2-deoxycytidine (5-Azadc; $2 \mu \mathrm{g} / \mathrm{mL}$ ) for 72 hours. 

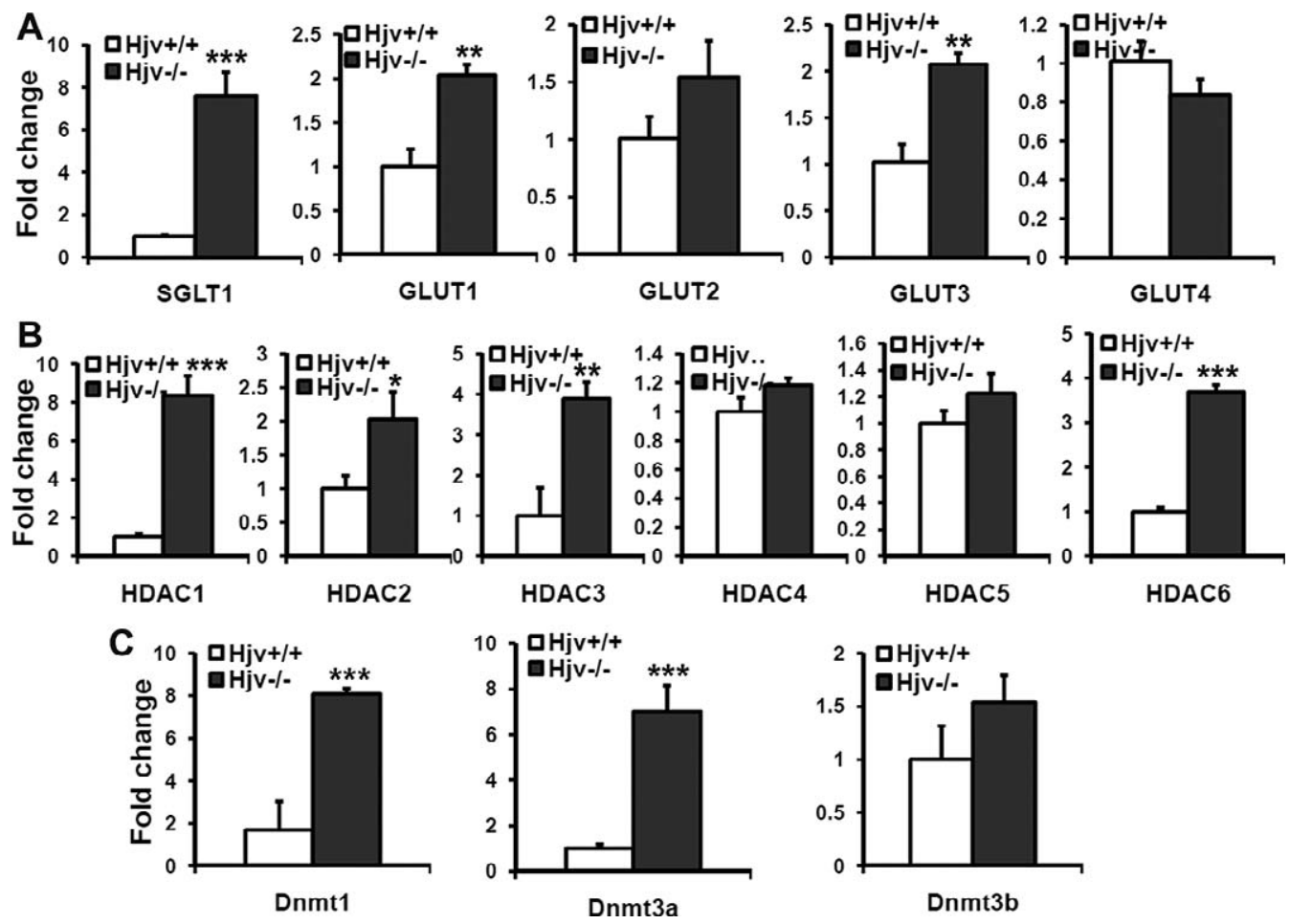

Figure 8. Changes in the expression of glucose transporters, histone deacetylases, and DNMTs in $\mathrm{Hj}^{-/-}$primary RPE cells. (A) Real-time PCR analysis for mRNAs of SGLT1 and GLUTs (A), HDACs (B), and DNMTs (C) in $H j v^{+/+}$and $H j v^{-/-}$RPE cells (P4). The experiments were repeated three times, and $18 \mathrm{~S}$ RNA was used as the internal control.

accumulation of iron in systemic circulation as well as in several organs, including the retina. Thus, iron overload is likely to be the common trigger for the observed biochemical and genetic alterations in $\mathrm{Hfe}^{-/-}$and $\mathrm{Hjv}^{-/-}$RPE cells. However, the molecular events linking the excessive iron to the tumor phenotype in these cells remain unknown. Iron overload is known to increase the production of reactive oxygen species, which not only cause oxidative stress but also serve as important signaling molecules. Iron is also obligatory for epigenetic modifications as many of the DNA demethylases contain iron at their active site. Since the biological role of iron is so widespread, it is difficult at this point to speculate on the most plausible mechanisms by which excessive iron induce a tumor phenotype in RPE cells. However, RPE hypertrophy observed in other mouse models suggests iron-induced oxidative stress is most likely to be the trigger for the hyperproliferative phenotype in this cell. In addition to our own studies on $\mathrm{Hfe}^{-/-}$and $\mathrm{Hjv}^{-/-}$mice, in which excessive iron accumulation in the retina is associated with RPE hypertrophy, ${ }^{17,18}$ four other mouse models have been described in the literature with a similar phenotype: ceruloplasmin/hephaestin double-knockout mouse, ${ }^{16}$ hepcidin knockout mouse, ${ }^{41} \mathrm{BMPO}^{-/-}$knockout mouse, ${ }^{42}$ and mouse with postnatal ablation of RPE mitochondrial phosphorylation. ${ }^{43}$ Oxidative stress is a common factor in all these mouse models, pinpointing its role as a potential cause of RPE hypertrophy. It is important to mention here that even though deletion of Hfe in RPE cells induces various biochemical and genetic features that are observed in tumor cells, $\mathrm{Hfe}^{-/-} \mathrm{RPE}$ cells are not malignant and do not form tumors when xenografted into athymic nude mice. Based on these data, it seems that excessive iron accumulation in tissues itself is not sufficient to cause cancer, but it seems very likely that excessive iron accumulation might facilitate tumor progression. Since hemochromatosis is a genetic disorder of iron overload with high prevalence in humans, this disease might be a significant promoter of tumor development and growth.

\section{References}

1. Donovan A, Andrews NC. The molecular regulation of iron metabolism. Hematol J. 2004;5:373-380.

2. Fleming RE, Britton RS, Waheed A, Sly WS, Bacon BR. Pathophysiology of hereditary hemochromatosis. Semin Liver Dis. 2005;25:411-419.

3. Beutler E. Hemochromatosis: genetics and pathophysiology. Annu Rev Med. 2006;57:331-347.

4. Ganz T, Nemeth E. Hepcidin and regulation of body iron metabolism. Am J Physiol. 2006;290:G199-G203.

5. Fleming RE, Britton RS. Iron Imports. VI. HFE and regulation of intestinal iron absorption. Am J Pbysiol. 2006;290:G590G594.

6. Halliwell B, Gutteridge JM. Oxygen toxicity, oxygen radicals, transition metals and disease. Biochem J. 1984;219:1-14.

7. Feder JN, Gnirke A, Thomas W, et al. A novel MHC class I-like gene is mutated in patients with hereditary haemochromatosis. Nat Genet. 1996;13:399-408.

8. Wallace DF, Subramaniam VN. Non-HFE haemochromatosis. World J Gastroenterol. 2007;13:4690-4698.

9. Moiseyev G, Chen Y, Takahashi Y, Wu BX, Ma JX. RPE65 is the isomerohydrolase in the retinoid visual cycle. Proc Natl Acad Sci US A. 2005;102:12413-12418.

10. Chen H, Lukas TJ, Du N, Suyeoka G, Neufeld AH. Dysfunction of the retinal pigment epithelium with age: increased iron decreases phagocytosis and lysosomal activity. Invest $O p b$ thalmol Vis Sci. 2009;50:1895-1902.

11. Dentchev T, Hahn P, Dunaief JL. Strong labeling for iron and the iron-handling proteins ferritin and ferroportin in the photoreceptor layer in age-related macular degeneration. Arch Ophthalmol. 2005;123:1745-1746. 
12. Martin PM, Gnana-Prakasam JP, Roon P, Smith RG, Smith SB, Ganapathy V. Expression and polarized localization of the hemochromatosis gene product HFE in the retinal pigment epithelium. Invest Ophthalmol Vis Sci. 2006;47:4238-4244.

13. Gnana-Prakasam JP, Martin PM, Mysona BA, Roon P, Smith SB, Ganapathy V. Hepcidin expression in mouse retina and its regulation via lipopolysaccharide/Toll-like receptor-4 pathway independent of Hfe. Biochem J. 2008;411:79-88.

14. Gnana-Prakasam JP, Martin PM, Zhang M, Atherton SS, Smith SB, Ganapathy V. Expression of the iron-regulatory protein haemojuvelin in retina and its regulation during cytomegalovirus infection. Biochem J. 2009; 419:533-543.

15. Hahn P, Qian Y, Dentchev T, et al. Disruption of ceruloplasmin and hephaestin in mice causes retinal iron overload and retinal degeneration with features of age-related macular degeneration. Proc Natl Acad Sci U S A. 2004;101:13850-13855.

16. Hadziahmetovic M, Dentchev T, Song Y, et al. Ceruloplasmin/ hephaestin knockout mice model morphologic and molecular features of AMD. Invest Ophthalmol Vis Sci. 2008;49:27282736.

17. Gnana-Prakasam JP, Thangaraju M, Liu K, Martin PM, Smith SB, Ganapathy V. Absence of iron-regulatory protein HFE results in hyperproliferation of retinal pigment epithelium mediated by induction of cystine/glutamate transporter. Biochem J. 2009; 424:243-252.

18. Gnana-Prakasam JP, Tawfik A, Romej M, et al. Iron-mediated retinal degeneration in haemojuvelin-knockout mice. Biochem J. 2011;441:599-608.

19. Selby JV, Friedman GD. Epidemiologic evidence of an association between body iron stores and risk of cancer. Int J Cancer. 1988;41:677-682.

20. Ropero S, Esteller M. The role of histone deacetylases (HDACs) in human cancer. Mol Oncol. 2007;1:19-25.

21. Chen Z, Trotman LC, Shaffer D, et al. Crucial role of p53dependent cellular senescence in suppression of Ptendeficient tumorigenesis. Nature. 2005;436:725-730.

22. Campisi J. Cellular senescence as a tumor-suppressor mechanism. Trends Cell Biol. 2001;11:S27-S31.

23. Deveraux QL, Reed JC. IAP family proteins-suppressors of apoptosis. Genes Dev. 1999;13:239-252.

24. Cheung H, LaCasse EC, Korneluk RG. XIAP antagonism: strategies in cancer treatment. Clin Cancer Res. 2006;12: 3238-3242.

25. Calvo TB, Figueroa A, Pulido EG, Campelo RG, Aparicio LA. Potential role of sugar transporters in cancer and their relationship with anticancer therapy. Int J Endocrinol. 2010; 2010;pii:205357.

26. Matsuzu K, Segade F, Matsuzu U, Carter A, Bowden DW, Perrier ND. Differential expression of glucose transporters in normal and pathologic thyroid tissue. Thyroid. 2004;14:806-812.
27. Chan DA, Sutphin PD, Nguyen P, et al. Targeting GLUT1 and the Warburg effect in renal cell carcinoma by chemical synthetic lethality. Sci Transl Med. 2011;3: 94ra70.

28. Mathupala SP, Ko YH, Pedersen PL, Hexokinase II: Cancer's double-edged sword acting as both facilitator and gatekeeper of malignancy when bound to mitochondria. Oncogene. 2006; 25:4777-4786.

29. Gupta N, Miyauchi S, Martindale RG, et al. Upregulation of the amino acid transporter $\mathrm{ATB}^{\mathrm{O},+}$ (SLC6A14) in colorectal cancer and metastasis in humans. Biochim Biophys Acta. 2005;1741: 215-223

30. Gupta N, Prasad PD, Ghamande S, et al. Up-regulation of the amino acid transporter ATB $^{0,+}$ (SLC6A14) in carcinoma of the cervix. Gynecol Oncol. 2006;100:8-13.

31. Ganapathy V, Thangaraju M, Gopal E, et al. Sodium-coupled monocarboxylate transporters in normal tissue and in cancer. AAPS J. 2008;10:193-199.

32. Ganapathy V, Thangaraju M, Prasad PD. Nutrient transporters in cancer: relevance to Warburg hypothesis and beyond. Pharmacol Ther. 2009;121:29-40.

33. Johnstone RW. Histone-deacetylase inhibitors: novel drugs for the treatment of cancer. Nat Rev Drug Discov. 2002;1:287299.

34. Iizuka M, Smith MM. Functional consequences of histone modifications. Curr Opin Genet Dev. 2003;13:154-160.

35. Rountree MR, Bachman KE, Herman JG, Baylin SB. DNA methylation, chromatin inheritance, and cancer. Oncogene. 2001;20:3156-3165.

36. Altieri DC. Validating survivin as a cancer therapeutic target. Nat Rev Cancer. 2003;3:46-54.

37. Li F. Survivin study: what is the next wave? J Cell Physiol. 2003;197:8-29.

38. Geho DH, Bandle RW, Clair T, Liotta LA. Physiological mechanisms of tumor-cell invasion and migration. Physiology (Bethesda). 2005;20:194-200.

39. Ropero S, Esteller M. The role of histone deacetylases (HDACs) in human cancer. Mol Oncol. 2007;1:19-25.

40. Feser J, Truong D, Das C, et al. Elevated histone expression promotes life span extension. Mol Cell. 2010;39:724-735.

41. Hadziahmetovic M, Song Y, Ponnuru P, et al. Age-dependent retinal iron accumulation and degeneration in hepcidin knockout mice. Invest Ophthalmol Vis Sci. 2011;52:109-118.

42. Hadziahmetovic M, Song Y, Wolkow N, et al. Bmp6 regulates retinal iron homeostasis and has altered expression in agerelated macular degeneration. Am J Patbol. 2011;179:335348.

43. Zhao C, Yasumura D, Li X, et al. mTOR-mediated dedifferentiation of the retinal pigment epithelium initiates photoreceptor degeneration in mice. J Clin Invest. 2011;121:369-383. 